\title{
From Mesopotamia to the Nebraska State Capitol: Assyrian Revival and New American Meanings
}

Bertram Grosvenor Goodhue's influential 'prairie skyscraper' design for the Nebraska State Capitol, inaugurated in 1928, has long defied stylistic categorisation. A now greatly overlooked element of its unclassifiable style was noted in numerous assessments at the time which identified 'Oriental' 'Assyrian' or 'Assyrian-Babylonian' features which, despite (or because of) their associations with a deep antiquity, contributed to the new, distinctly American architecture of the building, and of its sculptural programme by Lee Lawrie. This article considers the Assyrianising tendencies of the Capitol in the context of Art Deco interest in 'revival' of ancient styles, and American civic architecture's engagement with the ancient Middle Eastern past as an origin of civilization. Goodhue's close collaboration with Lawrie, muralist Hildreth Meière, and 'symbologist' Hartley Burr Alexander exemplified the productive and creative application of revived ancient iconography, which was employed in Nebraska in the service of various historical narratives and as a reflection of the designers' aesthetic appreciation for Assyrian sculptures. Finally this article also investigates how the Capitol's treatment of the ancient Mesopotamian 'lawgiver' Hammurabi influenced 'Hammurabis' in subsequent sculptural contexts, including in the State Capitol of Louisiana, American federal government buildings, and the Oriental Institute of the University of Chicago. ${ }^{1}$

In 1929, the year after architect Bertram Grosvenor Goodhue's new State Capitol at Lincoln,

Nebraska (fig. 1) opened to the public, the Nebraska-based journal The Prairie Schooner

published a seven-page poem by a certain Rosemonde E. Richards, called simply 'The Nebraska

State Capitol'. ${ }^{1}$ In striking, ecstatic ekphrasis the poet indicated her appreciation for the

building's cutting edge modern design, a towering skyscraper rising from the prairies, and for its

elaborately planned sculptural programme celebrating the state, the family, agriculture, and the

sublime:

Over the shadowed door

And around the whole monument, Egypt and the Orient, Greece and Rome,

And all nations of the world

Have come to merge in one great architecture.

And later:

In the sloping walls

We fashioned a building of the Pharaohs.

But this is America,

\footnotetext{
${ }^{1}$ The initial research for this article was completed during a short-term Henri Frankfort Fellowship at the Warburg Institute, University of London; I am very grateful for their support. I am also grateful for the support of the British Academy for the funding of my postdoctoral fellowship, 'A New Antiquity: Western Reception and Revival of Ancient Assyria in Decorative Arts and Architecture, 1850-1935', which allowed me to continue this research. I also thank Karen Wagner and the team at the Office of the Nebraska Capitol Commission, who assisted in providing images for this article, the staff at the Library of Congress Manuscript Division, and the two anonymous peer reviewers whose comments were very helpful.
} 
And the times that go together

Have different ways.

The dignity of Morning shines over our souls,

And the long night of first Creation is ended.

Richards had identified a feature of the building that struck many observers: its simultaneous integration of the ancient and the modern, the civilisations of the past and the American present. Although she namechecks pharaohs, the most familiar patrons of ancient 'Oriental' monumental architecture, what she was reacting to was in reality a building whose Oriental influences lay further east: in the Assyrian cities of northern Mesopotamia.

It has only been partially recognised how frequently references to Assyrian iconography, and sometimes Mesopotamian history, can be found in American architectural sculpture of the early twentieth century. Assyrian influences had been available to artists only since the middle of the nineteenth century. Starting in the 1840s, French and British diplomats and adventurers stationed in Ottoman-controlled Mosul began to excavate the remains of the capital cities of the Neo-Assyrian Empire, which, at its height in the mid-seventh century BCE, was the largest the world had yet seen. This rediscovery led to the emergence of the discipline of Assyriology and made Assyrian monumental art and architectural elements familiar to an excited public, especially in France and the United Kingdom, where the earliest discoveries were removed to the Louvre and the British Museum. This was the first direct contact with cities and rulers mentioned in the Hebrew Bible and Classical histories, but never before physically in evidence. Over the rest of the nineteenth century and especially in the early twentieth century, further excavations in Mesopotamia (Ottoman territory before World War I and then the modern state of Iraq) revealed more sites with cuneiform tablets and inscriptions and more 'new' ancient art. Although Assyrian imagery had already started to appear in jewelry, orientalist paintings, and museum souvenirs from its mid-nineteenth century rediscovery, ${ }^{2}$ I would argue it was later, early 
twentieth century artists looking for 'new' influences with which to create consciously modern styles who were perhaps most intrigued by these Assyrian rediscoveries.

In the United States, Assyrian motifs appear in various architectural contexts, from private clubs and company headquarters to educational and civic institutions, mostly in Art Deco style and mostly in the 1920s and 1930s. The purposes and meanings of Assyrianisms vary, but two important trends can be observed. Most often, Assyrian Revival motifs are only one small part of a building's overall decorative programme, often one reference of many to world cultures or histories - for instance in libraries and civic institutions whose decorative programmes narrate the 'invention' of writing, law, or government. Equally important is that Assyrian, Persian, and Egyptian imagery may be equated or combined in one 'Orientalising' aesthetic, as in the 1929 Medinah Athletic Club skyscraper in Chicago (architect: Walter W. Ahlschlager), commissioned by the Shriners Organisation, whose esoteric reliefs draw on a broad range of Eastern historical influences. Both of these trends are exemplified in the Nebraska State Capitol.

Although the historical connotations of Assyria as an especially ancient, Biblicallyattested, 'original' civilisation were usually in the forefront of its meanings in these buildings, I would argue that many sculptors and architects in Deco styles clearly found inspiration in the aesthetics of Assyrian imagery, particularly its relatively flat look with clean lines, and shallow, flattened perspective, and the integration of Assyrian sculptural elements into the architectural mass of buildings. Deco artists were consciously looking to non-Classical influences in order to produce buildings that felt new and — though rooted in aesthetics of a geographically wideranging past—distinctly American. As we shall see, Goodhue’s Nebraska Capitol was widely considered to have succeeded in doing just this. In this climate, Mayan, Egyptian, Moorish, and 
Assyrian revivals were often used in similar ways and with similar effects, as alternatives to the Neo-Classical and Beaux Arts styles that were most familiar in American civic architecture. Among all the examples of Assyrianisms in American architecture of the period, the Nebraska State Capitol is distinguished in the pervasiveness of its Assyrian imagery and its careful integration into a wider symbolic programme which tells a story about the 'progress' of civilisation, to its culmination in the American (and specifically the Nebraskan) project. It is also a building whose creators explicitly acknowledged the influence of Assyrian architecture and imagery on their work.

Although Assyrian elements are only one among many in the Nebraska State Capitol's eclectic influences, Assyrianisms are worth narrowing in on because their presence in that building should be significant to both ancient historians and scholars of modern art and architecture. More than two thousand years after the last cuneiform inscriptions were carved into palaces and monuments of the Near East, someone in Nebraska was carving an Akkadian cuneiform inscription in Indiana Marble on the Great Plains of Nebraska; this is an afterlife of antiquity that archaeologists, scholars, and museum directors played roles in rebirthing. For those with interests in architecture of the twentieth century, the Assyrian themes in this and other Deco buildings can tell us about the ways that architects and sculptors sought out new influences and formulated new ideas through ancient references. Assyrianisms are especially striking because they are, to most audiences, relatively obscure (certainly when compared to Egyptian, Archaic Greek, or Moorish styles). It is important to recognise that some of the most prominent sculptors and architects of the period were dedicated to seeking out unusual ancient influences in ways that reveal an impressive range and depth of historical interest on their parts. 
In this article I will discuss the history of the Nebraska State Capitol's design and the reaction to its 'new style'. I will then consider each of the building's most notable 'Assyrianisms' in works by sculptor Lee Lawrie and muralist Hildreth Meière. ${ }^{3}$ Finally I will trace some ways that the Capitol's engagement with Assyrian imagery would be echoed in other buildings and imagery of the 1930s, and investigate the relationships between sculptors and designers and academics and academic institutions.

\section{Making the Nebraska Capitol: how the building came to be}

Goodhue's design for the Nebraska State Capitol was selected through an architectural competition, first mooted in 1919 and ultimately decided in 1921 by a panel including Nebraska's then-governor Samuel R. McKelvie and under the professional advice of Omahabased architect Thomas Kimball, then the head of the American Institute of Architects. ${ }^{4}$ Goodhue's plan stands out with almost comical boldness among various Neo-Classical domes submitted by other architects. ${ }^{5}$ The Boston-born Goodhue was perhaps at the right point in his career to take such risks. He was counted as one of the leading American architects of the day, first in his Boston-based practice in partnership with the established Ralph T. Cram and then later in practice by himself in New York. He was astonishingly busy, his practice throwing up flagship buildings for churches, universities, government bodies, and private individuals all around the country. His design for Nebraska was the daring experimentation of an architect secure in his reputation and his ability to work across styles - and ready to try something new. The Nebraska State Capitol has been widely considered the masterful culmination of his career, a career which had seen him move seamlessly from inventive, imposing Gothic Revival and Spanish Colonial Revival to the spare, monolithic modernism represented in Nebraska's prairie 
skyscraper. It also became an inadvertent memorial to his achievements when he died unexpectedly of a heart attack in 1924, before the building was completed.

Goodhue worked closely throughout his career with the sculptor Lee Lawrie, who provided the sculptural programme for the Nebraska State Capitol. Lawrie had come to Chicago from Germany as a boy. He began to work as a sculptor in architects' offices while still a teenager and studied with leading Beaux-Arts sculptor Augustus Saint-Gaudens, later earning an honorary degree from Yale, where he was an instructor, and a reputation as one of the foremost architectural sculptors of the period. ${ }^{6}$ Like Goodhue, he was phenomenally busy, often on Goodhue projects, but also with numerous other architects around the country. When Goodhue submitted the successful bid for the capitol he already intended that Lawrie would provide its sculptures, and angrily fought against an attempt by the Capitol Commission to put the sculptural work out to a general bid, which he described as an insult to Lawrie who had been 'my collaborator and not my employee in any sense on the competition drawings'.

Lawrie understood sculpture as there to 'do' something for a structure, a concept he thought had been better understood in times past. 'On buildings, the sculptor's object is not to make an outstanding detail as much as it is his job to help complete the building....The sculptures of Babylon, Egypt, Greece, and even of the Middle Ages were made almost entirely for and on buildings. The art museum is a recent invention...and sculpture in the early days was done for a reason'. ${ }^{8}$ Elsewhere he explained the ancient lineage of the sculptor as: 'the earliest of the architectural craftsmen...he carved the winged bull and other gods in Assyria'. ${ }^{9}$ Lawrie was then not only respectful of ancient aesthetics, but also of what he understood to be ancient ideals of sculpture as an active and meaningful part of a building's existence. Lawrie's understanding of architectural sculpture as an inherent part of the structure is reflected stylistically in his 
preference for integrating sculptural forms directly into the mass of a building. ${ }^{10}$ It is also easy therefore to understand why Goodhue so valued Lawrie as a friend and collaborator and worked so closely with him: in buildings they worked on together the distinction between 'architecture' and 'decoration' is blurred. Together they created buildings that emerged as one 'sculpted mass', in the expressive phrase of David Frazer Lewis. ${ }^{11}$

For interior work, most of the decoration was in the hands of Hildreth Meière, who designed a dizzying array of mosaics, stained glass, paintings, and even a large rug. Meière's extraordinary interior work will not be discussed in detail here, except in regard to one faithfully Assyrianising inner chamber door. Meière had also worked with Goodhue before, including on the National Academy of Sciences in Washington D.C., the last building Goodhue would live to see mostly completed, whose execution overlapped with that of the Nebraska Capitol. Meière was also a widely employed and deeply respected decorative artist of the early to mid-twentieth century-in part because of the work with Goodhue at this relatively early stage of her career. ${ }^{12}$ When Goodhue submitted his proposal to the Capitol Commission, he wanted to ensure that it would fulfill the Commission's brief to create:

An inspiring monument worthy of the State for which it stands; a thing of beauty, so conceived and fashioned as to properly record and exploit our civilization, aspirations, and patriotism, past, present, and future. ${ }^{13}$

For this purpose, he was put in touch with University of Nebraska philosopher, anthropologist, and polymath Hartley Burr Alexander who would serve, officially, as 'symbologist' on the project. Alexander would prove to be a major influence on the final form of the building, both before and especially after Goodhue's premature death, working closely with Goodhue, Lawrie, and Meière to produce an exquisitely planned and obsessively detailed iconographic programme. Alexander also worked with Goodhue as symbologist for his Los Angeles Central Library (also in progress at the time of Goodhue's death). 
Ultimately, this group produced an iconographic programme of extraordinary complexity and scope, incorporating the human, natural, and supernatural worlds, celebrating everything from the abstract 'geniuses' of the four elements to the Nebraskan prairie schoolmarm. Several themes dominate the iconography, all of them successfully perceived by Rosemonde E. Richards in her poem quoted at the beginning of this article. Progression through time from an antiquity, prehistoric and historic, to a culmination in the present is the most pervasive organising principle. In this contemporary culmination of history, we find the state, the white prairie family, and the civic activity of Nebraskan life (schools, churches, builders). Before the arrival of the white prairie family in Nebraska, the Native Americans and the natural world of the Great Plains exist in a timeless, expectant state, waiting in patient nobility to host the Nebraskan state and the civilisation it represents.

These iconographic schemes interacted with the space of the building such that historical narratives 'move' through or around the building while allegorical abstractions serve to orient the viewer. For instance, Meière's mosaic for the floor of the building's Rotunda features a central medallion depicting 'Mother Nature Enthroned between Agriculture and Industry', surrounded by four medallions showing allegorical figures, geniuses of the elements, related to the cardinal directions. These images are encircled by guilloche bands looping around the central medallion and twisting to surround each cardinal medallion. Within these bands are processions of animal life moving forward through time in evolutionary order from the earliest prehistoric to the relatively contemporary. ${ }^{14}$ Like the treatment of ancient civilisations, the prehistoric creatures represent an impossibly ancient antiquity which simultaneously proclaims the building's modernity: expressing the most up-to-date and scientific understandings of the past and its connection to the present. 
Although the iconography of the Nebraska State Capitol was especially complex and thoughtful, the narrative techniques employed in the decorative programme were hardly unusual in civic architecture of the period. As we will see later in this article, inscribing narrative histories and allegorical expressions of abstract values into architecture was common everywhere in the United States, not only in civic buildings of government and education, ${ }^{15}$ but also in commercial centres (like the Rockefeller Center in New York City, for which Lawrie provided distinctive sculptures, including his immediately recognisable Atlas, and on which Meière also worked and Alexander advised, and the AT\&T Long Distance Building in New York City for which Meière provided mosaics of Asia, Africa, Australia and Europe connected by glowing golden telephone wires).

Within the elaborate symbolic schemes of the Nebraska State House, Assyrianising imagery comes to serve several primary purposes: to anchor the building's historical narratives to the earliest periods of a linear history of man and mankind, serving as a starting point for 'progresses' of law, government, and agriculture, and to speak to a timeless agricultural and pastoral life-the latter, I will show, connecting Assyrian imagery in unexpected ways to the buildings Native American imagery and themes.

\section{Assessing the building's 'New Style'}

Richard's poem, quoted above, has already shown us how ordinary, educated citizens responded to the building: with great fervour and, at least in Richard's case, serious engagement with the building's symbolic aims. The architectural press was, though more restrained and content to express their appreciation in mere prose, more or less in agreement. The building was widely recognised as a crowning achievement of Goodhue's career and a significant moment in 
American civic architecture. From the time that it won the design competition in 1921 up through the mid-30s the building was frequently cited in the press as a standard bearer of modern design and an influencer. ${ }^{16}$

As McCready explains, observers have long struggled to define the 'style' of the building and its sculptures. ${ }^{17}$ The architect Sidney Fiske Kimball, ${ }^{18}$ writing in 1927, referred to 'Assyrian and Moorish' elements of the interiors. ${ }^{19}$ Shortly after the original plans won the competition, the American Magazine of Art explained: 'Mr. Goodhue is chiefly associated in the public's mind with work in the Gothic style, but his design for the State Capitol of Nebraska follows no definite style....The design is essentially original and unique'. ${ }^{20}$ Symbologist Alexander himself, writing of the building while it was in progress in the Nebraska State Journal, spoke of 'the Asiatic suggestion more or less conveyed by the whole form of the building', intensified in Lawrie's highly Assyrian buffalo-themed entrance; 'However his buffalo is splendidly autochthonous, conventionalised in a mode as new as the architecture itself'. Lawrie's work, like the building itself, Alexander suggests is 'Asiatic without being Asian', as well as 'Heraldic without being European', Greek and medieval without being either in style: 'He is doing precisely what Mr. Goodhue has done with the building as a whole: he has drawn from every source without adopting the formalisms of any of them, and he has fused all into a new and living style'. ${ }^{21}$ Writing shortly after the building was formally opened in 1928, the American Magazine of Art, which had earlier praised the competition entry's uniqueness, now confirmed that: 'its style is essentially its own'. ${ }^{22}$ They quote in full a brochure issued by the Nebraska Capitol Commission which boasted of the new building: 'Inspired by the ancient structures of Asia, of Greece, of Egypt, of Spain, and of the south-western American states, the architect has conceived something that is distinctly American'. ${ }^{23}$ 
More recently, writing in 1991, Philip Larson referred to it as 'somewhat AssyrianBabylonian', and a building which 'broke the chokehold of classicism' ${ }^{24}$ Writing in 1981, Zabel stresses that the period was an exciting time for archaeological rediscovery of the ancient past and suggests that, 'It is not surprising, then, that Goodhue incorporated much of the new, but, actually, very old, artistic styles into the Nebraska capitol'. Zabel understands the building's architectural form, not just its decoration, as incorporating significant Assyrian influences (as well as Egyptian and Byzantine), going so far as to include a plate from French excavator Victor Place's 1867 publication depicting the Dur-Sharrukin (modern Khorsabad) central palace gate. ${ }^{25}$ Against the plans and images of the Nebraska State Capitol, the archaeological reimagining of Dur-Sharrukin looks right at home. ${ }^{26}$

For my own part, I think that the 'Assyrian' nature of the building comes out predominantly in the decorative elements introduced by Lawrie and Meière, and not as characteristically in Goodhue's architectural design, although, as mentioned already, Lawrie's sculptures are skillfully blended with the overall structure. The skyscraper and its domed top are quite unAssyrian, and whatever influence Goodhue found in ancient Assyria or other 'Oriental' or 'Asiatic' styles, his design is nothing like the kitschy Assyrian Revival of the 1929 Samson Tire Company building in Los Angeles (architect: Morgan, Wall, and Clement), with its spiky crenellations and ziggurat-esque central mass, or the 1927 Missouri Theatre in St. Joseph, Missouri (architect: Boller Brothers), a fantasy Moorish-Assyrian cinema palace. McCready persuasively argues that Goodhue's design was most likely strongly influenced by the work of Finnish architect Eliel Saarinen, whose Helsinki Rail Station of 1908 certainly does exhibit strong connections to Goodhue's later work for Nebraska, especially in its clock tower, and of which Goodhue was a great admirer. ${ }^{27}$ Nonetheless, as Zabel's parallel to the Dur-Sharrukin 
central gate suggests, the most characteristically Assyrian-informed element of the architecture is found in the wide low arches around the building's entrance, which do indeed echo archaeological and art historical drawings of the reconstructed facades of Assyrian palaces, walls, and gates (though also, it should be noted, there is also perhaps some further inspiration here from Saarinen's wide arched entrance to the Helsinki Railway Station).

In this respect, it is important to consider the influence of academic re-imaginings, much more than drawings of photos of archaeological remains themselves, in influencing the styles of architects who saw them. ${ }^{28}$ Furthermore, the sparse, clean style of some of these reconstructions, born of various practical considerations (to make images that could be mass-produced while retaining clarity for academic understanding, to not over-step or speculate too wildly where there is an absence of surviving detail), I think came to be read as aesthetically desirable. ${ }^{29}$ Place's reconstruction of Dur-Sharrukin features a beautifully blank, texture-less stretch of (no longer surviving) upper wall which might be the sort of thing that impressed Goodhue for his Nebraska design in which large stretches of smooth stone present a monolithic and imposing spectacle, particular striking in the prairie setting.

In summary, we see that many writers, at the time and more recently, have noted the building's ability to incorporate various 'influences' while emerging as distinctly 'modern' and also distinctly 'American'. The 'Asiatic', 'Oriental', or 'Assyrian/Assyrian-Babylonian' are recurring descriptors. That so many diverse observers agree on the building's essential unclassifiability is an important index of how imaginative revival influences succeeded in creating a style that seemed to exist outside of previously established systems of reference: something truly and completely new. 


\section{Lawrie's Biblical Scenes}

The first notable Assyrianisms I will consider appear in historicising scenes that serve as part of a series of panels dedicated to the 'History of Law'. Planned by Lawrie and Goodhue, later modified through suggestions from Alexander, ${ }^{30}$ the panels are located around the entire building. There is a vague chronological logic to their placement, but this arrangement is not strict and often overtaken by thematic arrangements (for instance, on the building's south side, scenes showing the signing of the Declaration of Independence and the drafting of the United States Constitution form the wings of a triptych around a scene of English King John signing the Magna Carta). ${ }^{31}$

As several observers have noted, Lawrie allowed his style in these scenes to be guided by his historical subject matter, employing different styles for different historical periods. McCready describes these styles as: 'archaic Assyrian, classical Greek, narrative Roman, and simplified naturalism (applicable to panels dealing with historical events in the United States)' ${ }^{32}$ Lawrie used style, then, as a means to inscribe symbolic meaning. Style serves as a measure of chronological advance (and relatedly, 'civilisational' advance) and differentiates each scene not only through identifiable subject matter but also through aesthetics, so that the ancient Orient is immediately visually distinguished from the ancient West, European, and American scenes.

Lawrie employed his 'archaic Assyrian' style, and specific references to Assyrian relief imagery, in two of the three panels narrating 'Biblical law', the most ancient scenes included in the sequence. The first of these depicts a scene from Exodus (fig. 2), Moses' presentation of the Ten Commandments on stone tablets (specifically his abortive first attempt, indicated by the presence in the scene of a 'Golden Calf' inspired by Persian imagery from the site of Persepolis). The second scene shows Deborah, Israelite leader in Judges, hearing the pleading of a nude 
young girl and clothed elderly woman, manhandled by Assyrian-style male guards/soldiers (fig. 3). A third scene of the judgment of Solomon from 1 Kings is not noticeably orientalising; it follows Lawrie's somewhat chunky, Assyrian-derived style, but without the obvious Assyrian iconographic references of the other two Biblical panels.

Biblical scenes are perhaps the most common site for the revival of Assyrian motifs, across fine art, decorative arts, and book illustration. Soon after the excavation of Assyrian capitals in the 1840s Neo-Assyrian costume and sculptural decoration started showing up in orientalising paintings of Biblical scenes,${ }^{33}$ and remained features of Biblical illustration in Lawrie's time and in more modernist styles. ${ }^{34}$ The assumption that Assyrian imagery was an acceptable stand-in for Israelite imagery was axiomatic.

Not only stylistically inspired, Lawrie's scenes of Moses and of Deborah drew very direct iconographic details from Assyrian imagery in ways that suggest that Lawrie carried out extensive research to find inspiration from ancient sources. The Moses scene features Moses and Aaron in the style of Assyrian kings and crown princes, pervasive imagery that could have been derived from any publication on Assyrian palace art. As mentioned above, a 'Golden Calf' is imagined as a fifth century BCE Persepolis bull column-the same imagery that inspired Lawriedesigned bull column capitals in the building's vestibule (although his have their own Nebraskan twist: ears of corn added between the bulls). Reaching for more obscure source material, Lawrie gave his Moses scene an altar which borrows its iconography from the depiction of the throne of Sennacherib from Nineveh's Southwest Palace 'Lachish Reliefs', now in the collection of the British Museum. A similar degree of research and attention has been paid to Deborah's throne, where Lawrie has faithfully created in great detail a throne derived from Ashurbanipal's Nineveh North Palace 'Banquet Relief', in which it is occupied by his queen, Liballi-sharrat. Lawrie even 
allows his usually spare style to bow to the Assyrian design for these representations of furniture: elaborate, ornamental, and somewhat fussy.

What can this tell us about Lawrie's relationship to Assyrian imagery? Certainly, Lawrie was interested in historicising and historical accuracy as a positive goal in itself, although he was flexible in that respect (as we see in his introduction of Persian and Classicising motifs to the scene). But unlike Orientalist history paintings of the nineteenth century, historicism was not necessarily mandated by the form. Throughout the Capitol, and as explicitly indicated in Alexander's suggestions and explanations, the historically contingent is subordinated to the expression of abstracts, and everything aims at that 'new style' the building was so praised for. So far as Lawrie did let historicism guide his work it was, as McCready has pointed out, mostly reflected in his overall style and not in the sort of minor historical details that interested nineteenth century Orientalist painters. I believe that the only compelling explanation for Lawrie's careful integration of these minutely detailed depictions of Assyrian thrones is that they appealed to him aesthetically. Unlike earlier generations of fine artists who also borrowed Assyrian imagery for Biblical scenes, Lawrie wanted to adopt Assyrian principles as well as style - even including a characteristic Assyrian preference for elaborate figurative detail in their representations of furniture and man-made objects, as in the throne designs that Lawrie borrowed in his Moses and Deborah scenes.

\section{The Assyrian Bison}

In the dramas of law and lawgivers that adorned the outer walls of the building, Lawrie used Assyrian iconography and style in the service of a historical narrative, to indicate place in time and space through authentic imagery and aesthetics. But Lawrie's most inventive and original 
revival of Assyrian motifs is found in his design for four relief panels depicting bison on the balustrades of the staircase leading up to the north portal, the main entrance to the building (fig. 4). As the first elements encountered on the way to the Capitol's front entrance, the stairway establishes Native American culture and life as both foundational to and yet outside of the state itself: a step on the way to the building proper. Native American imagery is excluded from the narratives of progress that Mesopotamian and Hebrew civilisations form an early part of, excluded even from the realm of the human, set within the realm of the (vanishing) natural world (represented by animals, not people). ${ }^{35}$

Lawrie's bison however are aesthetically interconnected with his narratives of history and civilisation through their style, which is immediately recognisable for its Assyrianising tendencies. His bison are strongly indebted to the most famous of Assyrian art/architectural objects, the lamassu. The lamassu is the human-headed colossal winged bull which adorned and supported doorways and gateways of Assyrian citadels and palaces (fig. 5). Monumental in size, it immediately became the most recognisable symbol of Assyria, even a sort of metonym for Assyrian civilisation. In British excavator Austen Henry Layard's publications of his excavations and adventures in Nineveh, illustrations dramatise the movement of the lamassu from their original position and across continents. The Illustrated London News celebrated the arrival of lamassu at the British Museum and their display to a curious public. ${ }^{36}$ In political cartoons of the 1850s, Layard as or with lamassu variants was a recurring theme. ${ }^{37}$ Lamassu make appearances in Orientalist paintings of the nineteenth century, in the Assyrian pavilion of the 1854 Sydenham Crystal Palace, ${ }^{38}$ in museum souvenirs of the Victorian era (and of the modern day). Lamassu adorned the covers and frontispieces of various publications about Assyria, including numerous successive editions of Austen Henry Layard's various bestselling books on Nineveh. In Lawrie's 
own time, images of lamassu appeared in architectural decoration including the Fred F. French Building in New York City (architects: H. Douglas Ives and Sloan \& Robertson) and the Missouri Theatre in St. Joseph, Missouri (both 1927). ${ }^{39}$ Lawrie would also feature lamassu in his designs for the entrance to the Sterling Memorial Library at Yale (architect: James Gamble Rogers, taking over from an initial design by Goodhue), the decorations around his Bronze Doors for the Library of Congress Annex (architect: Paul Cret), and for the 'Statue of Civilization' for Goodhue's Los Angeles Central Library. ${ }^{40}$ The lamassu is the closest that Assyrian imagery comes to something that contemporary designers or architects might call 'iconic'.

For Lawrie, I suspect that the lamassu was appealing not just because of its relative fame and popularity. The lamassu perfectly represented Lawrie's ideal for architectural sculpture, serving as an integral part of the architectural structure. In Assyria, the lamassu was a supernaturally powerful protective guardian, this concept actualised in its structural role as a load-bearing support for arched entrances, and threshold between outside and inside. It achieved just the sort of harmony between idea and form that Alexander, Goodhue, and Lawrie were striving for in the Nebraska State Capitol.

In fact, Lawrie and Goodhue's original plans for the bison called for them to be even more Assyrian than they came out: they wanted them to have wings, and also initially imagined them as being integrated into the architectural mass of the building as an Assyrian lamassu was, not as the relief panels along the staircase that ultimately emerged, but with the sculpture of the bison forming the balustrade of the stair itself. ${ }^{41}$ Alexander was unhappy with this element and persuaded them to change the plans; he felt that a winged bison was inappropriate for the Nebraskan setting, ${ }^{42}$ a figure inauthentic to the mythology of the region's Native American 
tribes. ${ }^{43}$ He warned Goodhue: 'The winged bull will fairly bellow from the portal, not in the sense of the passing of the bison, as you mean it, but as a dead thing out of Ninevah [sic] or Persepolis. It is a symbol of a faith that is not only dead, but was never native; and it will leave with me, and I believe with the future, a feeling of sadness and failure, --like a Saint Sophia with Arabic prayers replacing Christian icons', ${ }^{44}$

As both 'symbologist' and resident 'local expert', Alexander's judgment won out, though Goodhue continued to feel ambivalent about the changes. ${ }^{45}$ Ultimately Lawrie's toned-down, unwinged bison reliefs are nonetheless still strongly recognisable as Assyrian-inspired in its style and iconography (which in this case are one and the same). From the tight, stylised spiral curls of its hair to the representation of a ruff that runs in a distinctive band under its stomach, the bison are very clearly 'Assyrianising' in style. ${ }^{46}$

Alexander's anxiety that Lawrie and Goodhue's Assyrianisms not deauthenticate the Native American theme begs the question why such strongly Assyrian-inspired imagery was considered suitable to a sculptural programme whose symbolism Alexander explained as follows:

The symbolism is primarily Indian, the bison and the maize having been the fundamental food sources of the Plains Indians as corn and cattle are for their white successors. Further, in Plains Indian legend the bison is commonly represented as the giver of the maize, while this animal and plant are intimately associated in the native ritual. These panels symbolize, therefore, not only the first human life of the Plains, that of the Red Man, in relation to its elemental sources, but also the elemental source of the human life which has followed. ${ }^{47}$

Each of the four bison is engraved with a quotation chosen by Alexander from his interpretations of Pawnee, Sioux, and Navajo songs and lore, and above each bison's head is inscribed the names of tribes resident (or formerly resident) in the Great Plains (the engraved quotations are placed across the body of the bison, in an arrangement that Goodhue specifically described as inspired by Assyrian lamassu, which are inscribed over the body). ${ }^{48}$ Native 
American culture is then represented by the bison, reflecting the perceived status of both bison and indigenous human as pseudo-mythical, now mostly vanished predecessors of the white settlers who built the Nebraskan State. ${ }^{49}$ The use of Assyrian imagery here then has a very different meaning than in the panels that integrate it into a historical progress of civilisation, associated not with a chronological point in (ancient) time, but with a static, pre-historicalthough in fact incredibly recent - past.

However, I would suggest that the lamassu-influence evident in the bison is also perhaps more subtly present in another of Lawrie's scenes of 'civilised progress', not as an element of the vanishing, pre-white world but as an aesthetic for the modern-day. This is in the culminating scene of the 'History of Law', depicting the admission of Nebraska to the Union (a scene added to Goodhue and Lawrie's programme by Alexander). ${ }^{50}$ The scene is represented symbolically by a figure of Columbia who sits atop a throne welcoming 'Nebraska', represented by a frontiersman, a frontierswoman, and two soldiers in Union and Confederate uniforms. Columbia's throne is represented as a stylised image of an American eagle, whose design is arguably indebted to the Assyrian guardian (fig. 6).

I want to be cautious about assigning to every winged figure a Neo-Assyrian antecedentLawrie had long been interested in wings and in their possibility as decorative motifs that could integrate in exciting and unusual ways into architectural space. ${ }^{51}$ However, it seems clear to me that a number of Lawrie's winged figures do draw specifically from Assyrian lamassu, his original design for the bison being the most obvious. There are several ways in which this particular eagle can be regarded as not only coincidentally similar to an Assyrian lamassu. The first is its use, in this case as furniture, which represents a transmutation of the function of the lamassu as gatekeeper and architectural support-like a lamassu, the representation is 
characterised therefore by a completely flat 'top' across the wings and head. The second diagnostic feature is the placement of the eagle's feet, open in a pacing movement, a distinctive characteristic of lamassu, and an element of their design that in the Assyrian context suggested movement and power, so that lamassu were simultaneously standing at rest and always on the prowl. ${ }^{52}$ Even as Lawrie cooperated on a historicising programme, applying Assyrian aesthetics where temporally appropriate and respecting Alexander's decision to remove the wings from his bison, he nonetheless integrated Assyrian imagery of power into this most American, and most Nebraskan, of scenes.

\section{Meière's Oriental Door}

The equation of Mesopotamian with Native American in Lawrie's lamassu-esque bison continues on two striking interior chamber doors, leading from the Rotunda into the East and West Legislative Chambers, which were designed by Lawrie and Meière respectively. Here it is Meière whose work shows Assyrian influence (fig. 7). Lawrie's door, to East Chamber (now the Warner Chamber and no longer used for legislative purposes after a shift from a bicameral to a unicameral system), was created first. It features a Native American man and woman standing on either side of a cross-shaped thunderbird motif which bisects the door horizontally and vertically. The thunderbird's wings end in stalks of corn, and fertility symbols abound. Meière's door, painted on leather, was created after Lawrie's was completed and needed to parallel it visually. Alexander suggested an outline:

The center part would be essentially the Gothic-arched tree pattern, which can be very handsome. On each side, we should have a figure, an Adam and an Eve. I think, however, that I should not make of them nude figures, but with Oriental tasseled garments, such as the old designs show....For the top of the pattern, I think a winged disk, as symbol of heaven would be very good. You could give the disk, which would divide into hemispheres where the doors open, a more brilliant 
color or at least a solid color, which would make it carry as an abstraction, while the wings would be very ornamental. ${ }^{53}$

He cautioned: 'Do not make it too Assyrian, but enough to give the Mesopotamian suggestion'. ${ }^{54}$ But Meière certainly ignored this last instruction, as well as his call for a 'Gothic' design, in favour of a fully Assyrian look. She followed very closely the iconography of what is now most commonly called the Neo-Assyrian Sacred Tree and its attendants. Leading American Orientalist of the time James Henry Breasted, whose influence on the Nebraska team's research is discussed in the section below, described this tree as a 'Babylonian Tree of Life', thus relating the imagery to Biblical ideas (scholars are now much more cautious about how to interpret the meaning of this iconography, though it is widely recognised as a highly symbolic, mystical image). ${ }^{55}$ In Meière's door, two figures, a man and a woman, stand to either side of the stylised tree, the man holding a hoe in hand, the woman a vessel (presumably of water). These practical agricultural tools take the place of the cultic cones and buckets, items associated with ritual purification, that appear in attendants' hands in Assyrian images; Assyrian esoteric symbolism replaced with a more down-to-earth celebration of human invention and control of the natural world. Above the tree, forming part of an ornamental border is a winged solar disk, inspired at least in part by Egyptian imagery but also by Assyrian depictions of the Sacred Tree in which the god Assur hovers above in a winged disk. ${ }^{56}$ Like the Native American couple across the Rotunda, the imagery seems to speak of agricultural origins, on the Great Plains specifically, and in the Middle East. ${ }^{57}$ Ancient 'Oriental' culture, represented through Assyrian style and iconography, is equated to Native American culture through the close parallelism of place, design, and symbolism to Lawrie's door, as predecessors or originators of a civilisation culminating in white settlers' tilling of the Nebraskan soil. 
At the time, detailed illustrations of Assyrian Sacred Trees could have been found in numerous publications of remains from Nimrud particularly, where the tree with two attendants features in numerous reliefs, the most famous and widely disseminated being the throne room relief of Ashurnasirpal II (883-859 BCE; the relief is now in the collection of the British Museum). Meière's bright colours actually serve to give some indication of what an Assyrian Sacred Tree might have looked like when painted. Re-creations of painted reliefs and imagery were common in books from the 1840s onwards; Layard's reimagining of an Assyrian palace interior of Ashurnasirpal's II Northwest Palace at Nimrud features a colourful Sacred Tree. ${ }^{58}$ Neo-Assyrian sacred trees are always flanked by attendees of identical or nearly identical types. The throne room image which is most likely to have served Meière as inspiration features the same king, Ashurnasirpal II, depicted twice, from different angles, flanked on each side by winged human genies. The king is the only human figure in Assyrian iconography to occupy this place around the tree. More frequently, the tree is flanked by two genies, winged supernatural creatures. These genies may be bird-headed or human (almost always male though a few examples feature beardless, apparently female genies), but two figures of the identical type always flank one tree. In Meière's door, however, this sort of symmetry and similarity has been replaced by a gendered complementarity which mirrors the building's overall interest in the nuclear family and heterosexual reproductivity. In Nebraska, the king and his genies are superseded by the productive ancient oriental heterosexual couple: inventing agriculture, and the frontier family.

This transformation aside, it is notable that Meière's illustration is stylistically highly faithful to its source. I would argue that Meière, like Lawrie, must have found the aesthetics of Assyrian art appealing. Given that Alexander's original brief suggested only vague orientalising 
tendencies and specifically asked for something not too Assyrian, Meière must have found her source material suitable enough for her own purposes to allow both its style and its iconography to guide her here. Again, it seems that one of the key figures behind the building's decorative programme drew inspiration from Assyrian imagery that went beyond merely the historical content or the 'authenticity' it connoted, especially as this scene is more symbolic than historic, and does not noticeably benefit from being more historically accurate.

\section{Lawrie's Hammurabi}

Finally I will turn to an example of a prominently featured Mesopotamian figure-though not an Assyrian and not noticeably indebted to Assyrian style. As well as the scenes of the History of Law, the exterior walls also host a related progression of 'Lawgivers', arrayed, like the historical sequence, at various points around the structure (fig. 8). The chronologically earliest Lawgiver is Hammurabi (fig. 9), the old Babylonian ruler whose so-called 'law code' was at the time widely described as the first true law code in history: a natural origin point. The famous Stele of Hammurabi, inscribed with this 'code' had been discovered in 1901-1902 excavations led by Jacques de Morgan at Susa in modern-day Iran and taken to the Louvre. ${ }^{59}$ Hammurabi had ruled a territorial empire from the city of Babylon, to the south of Assyria, in the early to mideighteenth century, long before the Neo-Assyrian kings established their empire in the tenth century. Yet Neo-Assyrian rulers would have understood themselves as culturally connected to this earlier ruler; his 'Code' was recopied by Assyrian scribal elites learning the classics of cuneiform literature and the ideals of kingship.

In the 1920s, Hammurabi was thought to have reigned significantly earlier than we now (very securely) believe. Writing in 1916 in Ancient Times: A History of the Early World, a book 
that Lawrie, Goodhue, and Alexander consulted extensively, James Henry Breasted dates his reign to around $2100{ }^{60}$ Breasted acknowledges that the Code is not in fact the 'first':

With his eye thus upon every comer of the land, alert, vigorous, and full of decision, the great king finally saw how necessary it was to bring into uniformity all the various and sometimes conflicting laws and business customs of the land. He therefore collected all the older written laws and usages of business and social life, and arranged them systematically. He improved them or added new laws where his own judgment deemed wise, and he then combined them into a great code or body of laws. ${ }^{61}$

For scholars like Breasted and the public he spoke to soon after the discovery of the stele, Hammurabi's Code shed new light Biblical traditions, with clear similarities between Hammurabi's Code and Biblical 'Codes' in the Pentateuch (especially in Exodus's 'Covenant Code'), in format and genre, and even in the wording and principles of certain individual laws. Its discovery thus generated not only scholarly interest, but lively public excitement. The Code was also seen as remarkably 'modern' in its concerns and was often described using contemporary legal terms to explain the unspoken principles that governed decisions. ${ }^{62}$ This is the context in which Lawrie's Hammurabi was selected to begin the Nebraska procession of Lawgivers.

Lawrie's Hammurabi is a severe figure, carved in the chunky, square style Lawrie often favoured, with the exaggerated brow and firm nose of 'The Sower', the statue that adorns the Nebraska State Capitol's tower, and Lawrie's Rockefeller Atlas. The figure clearly references Hammurabi's image at the top of his Stele; as there, Lawrie's Hammurabi wears a rounded cap and relatively non-descript draped robes. The folds of these robes melt into the balustrade; the figures of Lawrie's Lawgivers are especially good examples of his devotion to architectural sculpture as an integral part of an architectural structure. 
Most intriguingly, there is a cuneiform inscription in the balustrade below Hammurabi, and it is relatively accurate, ${ }^{63}$ and carefully chosen. The inscription recreates what we call Law 196:

šumma awīlum ìn mār awīlim uhtappid ìnsu uhappadu

If an awìlum ['noble man'] should blind the eye of another awīlum, they shall blind his eye. ${ }^{64}$

The reasons for choosing this law are clear: it has strong cultural resonances that suit the idea of a 'progression' in which Hammurabi is in direct contact with the modern civilisation of Nebraska, and further a progression in which modern civilisation is not just a neutral inheritor, but a moral improver on what came before. The law was immediately striking when the Code was first translated for its similarity to the 'eye for an eye' phrase that appears in several places in the Hebrew Bible, famous enough to be a familiar proverbial saying in western culture. It is given most succinctly in Leviticus (24:19-20): ${ }^{65}$

And if a man cause a blemish in his neighbor; as he hath done, so shall it be done to him: breach for breach, eye for eye, tooth for tooth; as he hath caused a blemish in a man, so shall it be rendered unto him.

In analysis of the time, it would have been understood that Exodus 'advanced on' the Hammurabi formulation, limiting punishment to the body of the wrongdoer (Hammurabi's version allowed for children to be taken in punishment for a father's crime) and thus, in the interpretations of the time, developing the sense of 'the individual'. ${ }^{66}$ Breasted assesses Hammurabi's laws in light of this evolutionary sense, as an admirable but imperfect first step:

Hammurapi's ${ }^{67}$ code insists on justice to the widow, the orphan, and the poor; but it also allows many of the old and naive ideas of justice to stand. Especially prominent is the principle that the punishment for an injury should require the infliction of the same injury on the culprit - the principle of 'an eye for an eye, a tooth for a tooth'. Injustice often resulted. ${ }^{68}$ 
What replaced this 'old and naive' idea? The Hammurabi and the Hebrew Bible 'eye for an eye' laws would also have immediately called to mind the New Testament 'Sermon on the Mount' in Matthew 5:38-39, which also has given rise to an instantly recognisable proverbial phrase:

Ye have heard that it was said, An eye for an eye, and a tooth for a tooth: but I say unto you, Resist not him that is evil: but whosoever smiteth thee on thy right cheek, turn to him the other also.

Jesus's teaching rejects the 'barbarism' of the Hebrew and Mesopotamian in favour of mercy, of 'turning the other cheek'. ${ }^{69}$ The thread of connection is clear, as is the 'upwards' moral trend, from Mesopotamia to the Israelite law, and finally to Christian mercy.

The presence of such an accurate cuneiform inscription so carefully chosen to speak to the building's narratives of progress requires explanation; clearly Lawrie and Alexander had access not just to Breasted's popular explanations of Hammurabi, but to an accurate summation of the meaning and significance of his laws, in cuneiform signs. ${ }^{70}$ In the discussion that follows I will look at 'Hammurabis' in other government buildings, and consider the connections that sculptors and architects had to academic institutions and academics.

\section{A proliferation of Hammurabis, and a Chicago connection}

Tracing a series of Hammurabis across several subsequent buildings can serve us as an excellent case study in how ideas disseminated among artists of the American Deco movement, often connected through mutual collaborators or projects, and how those artists researched their subjects. Lawrie's Hammurabi, with its meaningful cuneiform inscription, would serve as a very clear inspiration for another sculpture of Hammurabi with cuneiform inscription several years later, in a very similar context. In 1932, a new Louisiana State Capitol was inaugurated as the nation's second skyscraper state house (fig. 10). The new building was the brainchild of the state's famously autocratic governor, Huey P. Long, who was serving as Louisiana senator by 
the time it was completed (in an incredibly speedy year and a half, though not quick enough to meet Long's initial instruction that it be inaugurated while he was still governor). ${ }^{71}$ It was designed by New Orleans-based firm Weiss, Dreyfous, and Seiferth, who also designed Long's other major projects during his gubernatorial tenure, including a new governor's mansion (Long had the old one torn down by convicts from the State's prisons, over the objections of political rivals). ${ }^{72}$

The capitol is very clearly indebted to Goodhue's innovative design for the Nebraska State Capitol: a building that 'paraphrased Goodhue's state house in Nebraska without comparable artistic pretension or historical tradition' in the fair assessment of Hitchcock and Seale. ${ }^{73}$ This serves as another reminder that the Nebraska State Capitol was widely perceived as a gold standard for modern civic architecture, something that those with ambitions to greatness were eager to copy. The modernist style and the break with traditional forms of American government architecture no doubt served Long as a useful symbol of his aims: to sweep away old elites represented by the former Louisiana state house built in the mid-nineteenth century, and to introduce a politics and an architecture that was lofty but populist in its ideals. Ultimately the new Capitol would also become Long's tomb, after he was assassinated on its steps in 1935 and interred in its South Gardens.

Lawrie worked on the Louisiana State Capitol's sculptural programme, along with a number of other leading architectural sculptors. Like its Nebraskan inspiration, the building features a variety of iconographic programmes depicting abstract ideals and historical narratives of progress. These take on their own distinctly Louisianan attributes; pelican replaces bison as the celebrated animal, and Long himself appears in a frieze of Louisiana history, directing three men (presumably Weiss, Dreyfous, and Seiferth) in the building of the capitol, which rises 
behind them. Such transformations in subject matter and iconography indicate the flexibility these sorts of decorative methods, which can be adapted to different regional contexts as needed (and to the ego of a very unique local politician).

The Hammurabi in this Capitol was not one of Lawrie's contributions to the building, but was instead the work of Ulric Ellerhusen, another German-American immigrant, who had frequently worked with or under Lawrie, often on Goodhue designs. Ellerhusen's Hammurabi appears first in a procession continued by Akhenaten/Ikhnaton, Solon, and Justinian, overlooking the culmination of their law-making legacy —in this setting, no longer the arrival of white people on the Great Plains or the admission of Nebraska to the Union, but the signing of the Louisiana Code in $1824 .{ }^{74}$ The Hammurabi is suspiciously similar to Nebraska's Hammurabi in style, and rests his arms on a tablet with the exact same cuneiform inscription that appears in Nebraska. ${ }^{75}$ We can imagine, however, that this suspicious similarity probably had Lawrie's blessing, given that Lawrie and Ellerhusen were so often harmonious collaborators. Most notably, the two worked together on the sculptural programme for Goodhue's University Chapel (now the Rockefeller Memorial Chapel) at the University of Chicago, ompleted in 1928 but designed by Goodhue in the late 1910s and early 1920 s.$^{76}$ Lawrie, who was the primary sculptor, delegated all the upper sculptural work to Ellerhusen. Ellerhusen's contribution there included a series on 'The March of Religion', planned in consultation with Lawrie, which partakes of substantially the same ideological and iconographic schemes as the various 'Progresses' of the two state capitol buildings, and like them is ecumenical in its understanding of historical influence (Plato and Zoroaster figure alongside Jewish and Christian figures). ${ }^{77}$

Ellerhusen made other significant contributions to the University of Chicago's decorative environment, which might indicate to us how both Lawrie and Ellerhusen came by their 
cuneiform inscription. In 1931 Ellerhusen designed the sculptural programme for the new, purpose-built Oriental Institute, including its Tympanum 'East Teaching West', a frieze that sits above the entrance to the building (fig. 11) ${ }^{78}$ Ellerhusen's work here was executed from a concept personally conceived by James Henry Breasted, the author of the popular history that informed the historical programme of the Nebraska State Capitol and the Institute's director. Breasted wanted the frieze to show 'the transition of civilization from the ancient Orient to the West'.79

To this end, the relief features at its centre two men watched over by an Egyptian sundisk, one in the style of a skirted ancient Egyptian and the other a barely-clothed 'vigorous and aggressive figure of the West'. The Egyptian appears to be passing to the Western man a fragment of Egyptian inscribed statuary: the gift of writing (and the title to Oriental archaeological remains in a more literal interpretation). To each side, great architectural structures and great men represent each region, arrayed above the recumbent figures of a lion, for the Orient, and a bison, for the West. ${ }^{80}$ Here we come full circle: there is another Hammurabi among the Oriental rulers celebrated, less stylised than Ellerhusen's Louisiana version. The great architecture of the Orient includes the Sphinx, the Pyramids at Gizeh, and the ruins of Persepolis. The architectural best of the West is represented by the Athenian Acropolis, Notre-Dame Cathedral — and, perhaps amazingly, the Nebraska State Capitol! Larsen and Emberling both suggest that this surprising inclusion can be explained by a generational connection between the engineers or architects of the Oriental Institute and the Nebraska State Capitol. The connection was indeed a close one: the firm who are credited as architects for the Oriental Institute, Mayers, Murray \& Phillip was simply Goodhue Associates renamed after Goodhue's death in 1924. Most of their early work involved finishing up or realising projects that were first developed by 
Goodhue, including the Nebrasksa Capitol. Breasted himself described the architectural parentage of the Institute thus: 'Mr. Murray, of the Goodhue Associates, designed the building'. ${ }^{81}$ Given also that Ellerhusen was a regular collaborator with both Goodhue and Lawrie, this was also undoubtedly more than just a self-referential glorification for the Institute's architectural antecedents, but a case of Ellerhusen seizing an opportunity to pay tribute to his friends and collaborators, and memorialise Goodhue's crowning achievement. ${ }^{82}$

It should also be noted, however, that in 1931 the idea of the Nebraska State Capitol as a pinnacle of Western architecture was perhaps not so strange or surprising a claim as it might seem now. As we have seen already, Goodhue's Nebraska Capitol was widely understood in the architectural press and by other professionals as a high point for modern architecture, a structure which expressed the aims of civic Deco at its finest, and therefore as good a representation as any for American modernism. It was also a distinctively (Middle) American building, a skyscraper on the prairie. Such a structure unites American pride in urban modernity and its great architectural form (born in Chicago itself), and in the conquest of a glorious, wild, Western landscape. Once again, history stops not just in the white West, but in America, where the Oriental Institute was being established to outshine the great European centres of Orientalist, archaeological, and museum expertise.

Here I would also like to speculate that Breasted might have played a role not just in the creation of this Tympanum, but in Assyrian imagery-and text-in the work of Ellerhusen, Lawrie, and Goodhue, including the cuneiform inscription in Nebraska and Louisiana. As discussed earlier, Breasted's popular books were used by Alexander, Goodhue, and Lawrie as the source for the history of ancient law. But Breasted was also a personal correspondent of the trio throughout the process. As an advisor on the National Academy of Sciences building, Breasted 
visited Lawrie's studio in October 1923 alongside astronomer George Ellery Hale, a close friend of Goodhue's, and engineer Gano Dunn. The group were there to inspect Lawrie's sculptures for the National Academy of Sciences (in which Egyptian and Assyrian imagery also abound), but Lawrie and Breasted began discussing the Nebraska 'Lawgivers' in the process. Breasted asked Lawrie to wait on drafting his Akhnaton figure until Breasted could provide a better model, and was concerned about the spelling of the pharaoh Akhnaton's name-in line with scholarly bestpractice at the time, he advised Ikhnaton (today the name would most often be spelled as Akhenaten, though conventions still vary). ${ }^{83}$ A propos this small matter, Breasted was put in touch with Goodhue, and Lawrie refers to a multi-pronged back-and-forth correspondence between Breasted and the Nebraska team. ${ }^{84}$ When the Akhnaton spelling was ultimately decided upon for Nebraska inscriptions (against Breasted's interpretation), Goodhue remarked, 'Please goodness, Dr. Breasted never sees the building itself! ${ }^{85}$ Although the surviving documentation only concerns discussions of Egyptian imagery, Breasted's primary specialty, he was also an expert (at the time part of a small number of American experts) in ancient Mesopotamia. it is certainly possible that Breasted, or someone else at University of Chicago was asked to provide the cuneiform inscription for Lawrie's Hammurabi, later borrowed by Ellerhusen and to give advice on Mesopotamian imagery. ${ }^{86}$

A postscript is due here to note that Hammurabis also feature in sculptural programmes with similar themes in federal government buildings: the United States Supreme Court (architect: Cass Gilbert) features a frieze on its south wall which depicts Hammurabi between Egyptian Pharaoh Menes and Moses, in the muscular style of a Neo-Assyrian king or genie. ${ }^{87}$ Its sculptor Adolph A. Weinman had worked alongside Ellerhusen and Lawrie on the Louisiana State Capitol and was a friend of both, but his Hammurabi owes nothing to Lawrie's or Ellerhusen's 
interpretations. Weinman's research notes show him considering using either Neo-Assyrian costume, or the imagery from the 'bas relief' on the Stele of Hammurabi ${ }^{88}$ given that NeoAssyrian iconography was far more recognisable and widely disseminated than the Stele of Hammurabi's less detailed and distinctive imagery, it is likely that Weinman made the decision for aesthetic reasons, and perhaps also in the hopes of making his figure more recognisable as 'Near Eastern' in Neo-Assyrian, rather than Old Babylonian, dress (not a distinction over which anyone but an Assyriologist would trouble).

A decade later, in 1947 (finished in 1951), the House of Representatives would get its own Hammurabi, by artist Thomas Hudson Jones, in yet another lineup of the usual suspects of 'Lawgivers', in the House Chamber (fig. 12). ${ }^{89}$ This project was overseen by Lawrie as consulting sculptor, tasked with ensuring harmony among the different sculptors contributing to the 'Lawgivers' series. ${ }^{90}$ A profoundly more stylistically conservative sculpture, Jones' Hammurabi, like Lawrie's and Ellerhusen's, drew inspiration from the Stele of Hammurabi. However, Jones had done his research less well, or been more liberal in his interpretations: his 'Hammurabi' is actually inspired by the depiction on the Stele of the sun god Shamash, wearing the horned crown associated in Mesopotamia with divinity, and not Hammurabi's rounded royal hat. It seems likely that Jones presumed that the figure seated on a throne and receiving adoration must be the king. Through this careless research, Jones, presumably unintentionally, placed a pagan god in the United States Capitol (the problem was also not noticed by Lawrie, who did advise changes to Jones' original design so that the beard sat forward on the chest in a more Babylonian style and so that the 'turban' more realistically seemed to wrap a head). ${ }^{91}$ The House of Representatives programme is different in another significant way from its 1920s and 1930s predecessors: while they constituted more or less straightforward 'progressions' through 
chronological time, the House of Representatives' lawgivers are grouped around and looking towards a representation of Moses, who alone is depicted full-face. The meaning of this 'progress' is thus profoundly transformed. Whereas the Nebraska Moses sits between equals, no different than Hammurabi, Akhnaton or Solon, his ancient texts reproduced like their ancient texts, the Moses of the House of Representatives is elevated above and removed from a linear historical 'progress'.

\section{Conclusion}

It is clear that 'Assyrian Revival' elements in architectural sculpture were remarkably adaptable. This is apparent in the Assyrian elements in the Nebraska State Capitol and the impact that this building's sculptural programme and aesthetic ideals had on other buildings of the era. In the Nebraska State Capitol, Assyria was used for a few primary purposes. In its historicism, and venerable age, it could represent Biblical scenes as well as imagined mythical 'predecessors' in the invention of agriculture and civilisation. With the iconography adjusted to its new American contexts, it also somewhat surprisingly came to be integrated with the Native Americans who, like the Assyrians, were understood as 'predecessors' of the white settlers on the Nebraska plain: both the ancient Orient and the very recent indigenous inhabitants of North America a venerated but vanished, superseded earlier stage in the building's, and the State's narrative.

Yet Assyrian imagery was not only valuable for the ideas it evoked, but because of its stylistic and aesthetic qualities. It is clear in the work of Goodhue, Meière, and especially of Lawrie that they were moved to reproduce the styles and aesthetics that they found in Assyrian sources. The Assyrian ability to integrate sculptural form, as in the lamassu, with architectural function also inspired them towards what Lawrie understood to be a generically 'ancient' idea of 
sculpture, decoration, and architecture as unified and indistinguishable. In this respect, they were different from many artists who had gone before them, for whom Assyrian imagery was valuable for its antiquity but not necessarily on its own aesthetic merits. In the Nebraska State Capitol, Assyrian imagery constituted a worthy 'new' inspiration, somehow simultaneously modern and ancient.

The clear sharing of interests and information and the interconnection among civic buildings of the time also reveals the highly interconnected climate in which American Deco artists, architects, and the civic commissions who employed them operated. It was a climate in which artists and architects collaborated in multiple projects and monitored and learned from each other's work. Information-sharing was clearly taking place between collaborators, and from prominent academics, in personal correspondence and through popularising books.

Assyrian and more broadly ancient Oriental influences were explicitly recognised by sculptors and architects, architectural press, and the general public. We find praise for the antique or Oriental aspect of the Nebraska State Capitol and its integration with American modernity in journals and even, as the poem that opens this article indicates, in literature. Notably, the influences from ancient Oriental cultures were understood by all as an aspect of what made the building 'modern'. This is the central, paradoxical appeal of 'revival' in Art Deco art and architecture: something that is simultaneously more ancient than could have been imagined before archaeological discoveries of the nineteenth and twentieth centuries - and thereby utterly modern. In this schema Assyria emerged as particularly compelling and flexible, nowhere more so than in the sculptural programme of the Nebraska State Capitol.

\footnotetext{
${ }^{1}$ R. E. Richards, 'The Nebraska State Capitol', Prairie Schooner 3, no. 2, 1929, pp. 81-87.

${ }^{2}$ On the mania for Assyrian imagery in the aftermath of the rediscovery of Assyrian capitals in the 1840s in Europe, see F. N. Bohrer, Orientalism and Visual Culture: Imagining Mesopotamia in Nineteenth Century Europe, Cambridge, Cambridge University Press, 2003; S. W. Holloway, 'Biblical Assyria and Other Anxieties in the British
} 
Empire', Journal of Religion \& Society, vol. 3, 2001, pp. 1-19 at pp. 3-6. For useful studies of the earliest American public interest and academic engagement with Near Eastern archaeology and Assyrian finds, see S. W. Holloway, 'Nineveh Sails for the New World: Assyria Envisioned by Nineteenth-Century America', Iraq, vol. 66, 2004, pp. 243-256; A. Cohen and S. E. Kangas, 'Our Nineveh Enterprise', in A. Cohen and S. E. Kangas (eds), Assyrian Reliefs from the Palace of Ashurnasirpal II: A Cultural Biography, Hanover, New Hampshire, Hood Museum of Art, 2010, pp. 1-47; B. Kuklick Puritans in Babylon:The Ancient Near East and American Intellectual Life, 18801930, Princeton, Princeton University Press, 1996.

${ }^{3}$ I leave out the work of painter Augustus Vincent Tack, who painted murals for the Governor's Chambers of the Capitol, since Tack was not as involved in decisions about the overall scope of the building as were Lawrie and Meière. One piece, an 'Allegorical Painting Representing Divine Attributes of Understanding, Justice and Mercy' on the East Wall of the Governor's reception room, features a man in Assyrian-Babylonian dress representing 'Babylonia'. See L. Mechlin, 'Mural Decorations by Augustus Vincent Tack, Nebraska State Capitol', The American Magazine of Art, vol. 19, no. 1, 1928, pp. 5-12; F. C. Luebke, 'The Progressive Context of the Nebraska Capitol: The Collaboration of Goodhue and Tack', Great Plains Quarterly, vol. 15, no. 4, 1995, pp. 227-245.

${ }^{4}$ E. S. McCready, 'The Nebraska State Capitol: Its Design, Background and Influence', Nebraska History, vol. 55, 1974, pp. 325-461 at pp. 330-331.

${ }^{5}$ For an analysis of the competition see E. G. Grossman, 'Two Postwar Competitions: The Nebraska State Capitol and the Kansas City Liberty Memorial', Journal of the Society of Architectural Historians, vol. 45, no. 3 , 1986, pp. 244-269; J. R. Stillgoe, 'Modern Design Competitions: Three Case Studies', Journal of Architectural Education, vol. 35, no. 4, 1982, pp. 22-26.

The two competitions Grossman looks at were both for large civic buildings in Middle American states, and both set standards for cutting edge architectural work, as did, even more famously, the 1922 Chicago Tribune Tower competition in the Midwest's largest city, one of Stillgoe's case studies. As I go on to consider the influence of the Nebraska State Capitol on other buildings and its recognition in its own time as a high point of modern American architecture, this dynamic is important to note: in the 1920s, the most exciting architecture was often being executed in Middle America, often in mid-sized cities, and often through highly publicised competitions in which local civic or business leaders deliberately courted the best and most exciting architectural ideas. The attraction of such competitions to leading architects was perhaps in the chance to literally put these cities on the architectural map, to create something that would define the identity of growing cities whose physical fabric was still highly mutable.

${ }^{6}$ On Lawrie's childhood and career development, see A. Schwartzman and S. Gee. Los Angeles Central Library: A History of Its Art and Architecture, Los Angeles, Angel City Press, 2016, pp. 111-113.

${ }^{7}$ Goodhue Correspondence in Nebraska Capitol Commission. Goodhue letter to William E. Hardy, June 14,1921. Quoted O. H. Zabel, 'History in Stone: The Story in Sculpture on the Exterior of the Nebraska Capitol', Nebraska History, vol. 62, 1981, pp. 285-372 at p. 289.

8 'Lawrie's Creed', The Art Digest, vol. 6, 1932, p. 29.

${ }^{9}$ L. Lawrie, Modern Mural Sculpture, Pasadena, Esto Publishing, 1934.

${ }^{10}$ This tendency was often remarked upon, as both a positive and a negative aspect of his work in the architectural press of the time. One assessment vacillated: 'None of them [other leading sculptors] has collaborated more sympathetically with architects than Lee Lawrie. Perhaps at times he has been willing to subordinate his sculpture overmuch, and he has certainly been too dependent on the Egyptian tradition....But great praise must be given him for the sculpture decorating the Nebraska State Capitol'. W. R. Agard, 'American Architectural Sculpture', The American Magazine of Art, vol. 24, no. 3, 1932, pp. 205-212 at p. 210. See also L. Cross, 'The Sculpture for Rockefeller Center', Parnassus, vol. 4, no. 5, 1932, pp. 1-3 at p. 2.

${ }^{11}$ D. F. Lewis, 'The Ideal of Architecture as Sculpted Mass during the Interwar Period', Sculpture Journal, vol. 25, no. 3, 2016, pp. 343-360. Lewis is interested in British architecture of the period, but cites Lawrie and Goodhue's collaborations as influential on British architects striving for this ideal.

${ }^{12}$ C. C. Brawer and K. M. Skolnik. The Art Deco Murals of Hildreth Meière, New York, Andrea Monfried Editions, 2014, p. 79.

${ }^{13}$ The Nebraska Capitol Commission, 'Final Stage of Competition for the Selection of an Architect to design and supervise the construction of a Capitol for the State of Nebraska'; published as Appendix II in McCready, as at note 4 , p. 433.

${ }^{14}$ As at note 12 , pp. 65-68.

${ }^{15}$ For example, Goodhue, Lawrie, and Alexander applied similar principles to their collaboration on the Los Angeles Central Library, which was also inscribed with a series of interlacing and interacting schemes, on the themes of literature, writing, and wisdom. These series included Assyrian-Babylonian imagery on a 'Well of Scribes' and Lawrie's 'Statue of Civilization'. See Schwartzman and Gee, as at note 6, pp. 91, 104-105. 


\footnotetext{
${ }^{16}$ See for instance the assessments in J. S. Dickerson, 'The University of Chicago Chapel', The American Magazine of Art, vol. 19, no. 12, 1928, pp. 681-689 at p. 684; 'North Dakota's New Capitol', The American Magazine of Art, vol. 27, no. 3, 1934, pp. 143.

When Goodhue soon after was selected as the architect for the Los Angeles Central Library, his unbuilt, winning Nebraska competition entry was praised by the committee, and cited as already a crowning achievement justifying his selections; see Schwartzman and Gee, as at note 6, p. 24. On Lawrie's Nebraska sculpture as a gold standard within American architecture, see Agard, as at note 10, pp. 209-210.

${ }^{17}$ As at note 4, p. 363.

${ }^{18}$ No relationship to Thomas Kimball, who served as the professional advisor to the Nebraska Capitol Commission.

${ }^{19}$ S. Fiske Kimball, 'Goodhue's Architecture, A Critical Estimate', Architectural Record, vol. 62, no. 6, 1927, p. 538.

20 'Two Notable Works in Architecture', The American Magazine of Art, vol. 12, no. 10, 1921, pp. 355.

${ }^{21}$ H. B. Alexander, 'Nebraska's Monumental Capitol at Lincoln', The Nebraska State Journal, 18 Nov. 1923, p. 6 .

22 'The Nebraska Capitol', The American Magazine of Art, vol. 19, no. 1, 1928, pp. 3-4 at p. 3.

${ }^{23}$ Ibid., 4.

${ }^{24}$ P. Larson, 'Cass Gilbert: Civic Classics vs. Gotham Goths', The Print Collector's Newsletter, vol. 22, no. 4, 1991, pp. $120-125$ at p. 124.
}

${ }^{25}$ Zabel, as at note 7, pp. 296-297; V. Place, Ninive et l'Assyrie, avec des essais de restauration par F. Thomas, vol. 3, Paris, Imprimerie Impériale, 1867, pl. 21.

${ }^{26}$ Against these interpretations of the building's radical newness, Luebke sees Goodhue's design as fundamentally conservative at heart, preserving Progressive Era ideals of Beaux Arts symmetry and proportion while stripping away unnecessary details. As at note 3, pp. 229-232.

${ }^{27}$ McCready, as at note 4, p. 363. Incidentally, this admiration was mutual: Saarinen delivered a touching dualeulogy of Goodhue and Louis Sullivan shortly after their deaths in 1924, while he was visiting the United States. Speaking of Goodhue, he writes: 'I thought of his majestic Capitol Building for the state of Nebraska, now and construction; and I perceived how his development has gone towards Simplicity and Truth in his sincere search and tireless striving'. Saarinen also reminisces about a past meeting with Goodhue in his home, being shown works in progress in his studio. He observes how lucky America was to have Goodhue as its trail-blazer and one of its greatest architects. Eliel Saarinen, 'Louis Sullivan, Bertram Grosvenor Goodhue in Memoriam', April 27 $7^{\text {th }}, 1924$. Archives of American Art, Smithsonian Institution Washington, D.C.

${ }^{28}$ The relationship between archaeological reconstruction and architectural drawing emerges especially strongly in the publications produced from German excavations at Babylon and Assur in the early twentieth century. A number of the archaeologists working at these sites had originally trained as architects, including Walter Andrae who led the Assur excavations and took over Babylon excavations from Robert Koldewey, and who oversaw the reconstruction of Babylon's Ishtar Gate in Berlin. As Brusius argues, Koldewey and Andrae were interested in the entire context of the site and saw each object as valuable, in contrast to German Orientalist colleagues whose obsession with cuneiform tablets frustrated them. The German excavations were the most 'scientific', state-of-theart excavations and publications of their time, and the training excavators had in producing architectural plans informed how they approached documenting the site. It also surely informed their approach to the sites as significant spaces in total, and not simply a resource for cuneiform texts or displace-able art objects. See M. Brusius, 'The Field in the Museum: Puzzling out Babylon in Berlin', Osiris, vol. 32, 2017, pp. 264-285.

For more on this subject see J. M. Córdoba, 'Walter Andrae und die Wiederentdeckung Assurs das abenteuer der architektonischen zeichnung innerhalb der archäologie des alten orients', Isimu, vol. 6, 2016, pp. 35-60; M. G. Micale, 'European Images of the Ancient Near East at the Beginnings of the Twentieth Century', in N. Schlanger and J. Nordbladh (eds), Archives, Ancestors, Practices: Archaeology in the Light of Its History, New York, Berghahn Books, 2008, pp. 191-203; F. Pedde, 'The Assur-Project: An Old Excavation Newly Analyzed', in J. M. Córdoba (ed.), Proceedings of the 5th International Congress on the Archaeology of the Ancient Near East, Madrid, Ediciones Universidad Autónoma de Madrid, 2008, pp. 743-752.

${ }^{29}$ Not all re-imaginings have this characteristic stylistic sparseness, however. Austen Henry Layard's 1849 collection of plates Monuments of Nineveh, one of the earliest disseminations of Assyrian imagery to a wider British public, opens with the author's watercolour reconstruction of an Assyrian throne room which is densely, elaborately detailed and very speculative; among other things it fills in a very grand, very Victorian ceiling; see A. H. Layard, The Monuments of Nineveh: From Drawings Made on the Spot, London, John Murray, 1849, pl. 2. This highly 
influential reconstruction has been the subject of a short, incredibly thorough recent study, A. Cohen and S. E. Kangas, Inside an Assyrian Palace: Looking at Austen Henry Layard's Reconstruction, Hanover, New Hampshire, Hood Museum of Art, 2017. The authors consider the importance of this one Layard reconstruction to the history of the discipline, and as a window into the Victorian imagination of the ancient world.

Also highly influential was an equally sumptuous, and fanciful, watercolour reconstruction of the palaces and ziggurats of ancient Nimrud rising above the Tigris in the sequel, A. H. Layard, The Monuments of Nineveh, Including Bas-Reliefs from the Palace of Sennacherib and Bronzes from the Ruins of Nimroud: From Drawings Made on the Spot, during a Second Expedition to Assyria, London, John Murray, 1853, pl. 1.

${ }^{30}$ R. Haller, 'The Drama of Law in the Nebraska State Capitol: Sculpture and Inscriptions', Great Plains Quarterly, vol. 13, no. 1, 1993, pp. 3-20 at p. 4.

${ }^{31}$ For the clearest overview of the placement of various sculptural elements around the building's exterior, see the diagrams in Zabel, as at note 7, pp. 301-304.

${ }^{32}$ As at note 4, pp. 384-385. See also Zabel, as at note 7, p. 299.

${ }^{33}$ Some examples from around Europe include Edward Armitage's Festival of Esther, 1865; Ernst Josephson's David och Saul, 1878; Edwin Long's The Assyrian Captive, 1880; Julius Kronberg's David och Saul, 1885; Ernest Normand's Esther Denouncing Haman, 1888. In all these instances, Assyrian reliefs or lamassu feature in the background of Biblical scenes taking place in Israelite, Persian, or Assyrian courts, and costume borrows from Assyrian iconography. For a detailed overview of Assyrian imagery in nineteenth century fine art, see Bohrer, as at note 2, 84-97, 191-206, 256-271.

${ }^{34}$ See for instance the work of French painter and illustrator Jacques James Tissot, who between the late 1880s and the very early years of the twentieth century created numerous Orientalist illustrations and paintings of Biblical scenes, shown in France and the United States and published in book form; and the more radical jugendstil modernist E.M. Lilien, who uses Assyrian imagery in various places in his work, most persistently in various renditions of a Moses who also looks strikingly like his friend Theodor Herzl. In this latter context, the authenticity of the Oriental imagery supported Lilien's Zionist arguments for a return of Jews to a Near Eastern homeland and celebrated ancient traditions reawakened in the Zionist 'New Jew'.

${ }^{35}$ The bison nonetheless do conform to one aspect of civilisation as imagined in the rest of the Capitol: they form two-parent nuclear families (in which the woman takes primary childcare responsibility), with each balustrade pairing a male bull standing alone on one side and a female bison with child on the other the other.

${ }^{36}$ M. Brusius, 'Misfit Objects: Layard's Excavations in Ancient Mesopotamia and the Biblical Imagination in Mid-Nineteenth Century Britain', The Journal of Literature and Science, vol. 5, Jan. 2012, pp. 38-52.

${ }^{37}$ S. Malley, From Archaeology to Spectacle in Victorian Britain: The Case of Assyria, 1845-1854, London, Routledge, 2016, 119-125.

38 The Crystal Palace was initially erected at Hyde Park for the Great Exhibition of 1851 but was relocated to a permanent home in Sydenham Park in 1854, where it stood until the building burned down in 1936. The Nineveh Court was introduced only to the 1854 version. A periodical a few years after it opened instructed visitors to marvel and learn from it: 'It is but a few years since the originals, serving as models for this Court, were discovered; consequently these sculptured tablets, winged bulls, symbol painted walls, and extraordinary effigies of combined human and brute beings, are facsimiles of newly resuscitated remains of the past; displaying likewise remarkable architectural and sculptural features, previously unknown to man for aces anterior to the Christian era. Examine them well, for they will impart to you many new and valuable ideas'; 'A Day at the Crystal Palace', The Leisure Hour, vol. 5, 1856, pp. 631-636 at 635.

For more on the Nineveh Pavilion, see D. Thomas, 'Assyrian Monsters and Domestic Chimeras', Studies in English Literature, 1500-1900, vol. 48, no. 4, 2008, pp. 897-909 at pp. 897-901; M. Digby Wyatt, Views of the Crystal Palace and Park, Sydenham, London, Day and Son, 1854, pp. 20-21; A. H. Layard, The Nineveh Court at the Sydenham Crystal Palace, London, Bradbury \& Evans, 1854.

${ }^{39}$ Lamassu are an element of the monumental sets for D.W. Griffith's Intolerance (1916), but with surprisingly little emphasis, only just visible in certain shots. They are more prominently featured in Michael Curtiz's (then working as Mihály Kertész) Sodom und Gomorrha (1922).

For images and discussion of the set of the latter see R. Heilmann, “That Old Time Religion": Der Einsatz von Mythen am Beispeil des Films Sodom und Gomorrha', in A. Loacker and I. Steiner (eds), Imaginierte Antike: Österreichische Monumental-Stummfilme, Vienna, Filmarchiv Austria, 2002, pp. 93-110; A. Kümmel, 'Millionen Kleiner, Wechseinder Gesichter: Die Rechtfertigung der Oberfläche vor Ihren Verächtern', in Imaginierte Antike: Österreichische Monumental-Stummfilme, pp. 389-415, at p. 408. 
${ }^{40}$ Yale University Library, 'Yale University Library Gazette Special Issue on The Sterling Memorial Library, Volume V, Number 4 (April 1931)', Publications on Yale History, Apr. 1931, p. 81; Schwartzman and Gee, as at note 6, pp. 104-105.

${ }^{41}$ An early drawing of the North Entrance with bison as frieze panels but still sporting wings can be seen in the 1926 publication 'The Nebraska Capitol', put out by the Nebraska Capitol Commission.

${ }^{42}$ Since the 1880s Alexander had been researching and writing on myth, ritual, and 'Indian Religion' especially in the Great Plains and the Southwest. T. M. Alexander, 'The Life and Work of Hartley Burr Alexander', The Pluralist, vol. 3, no. 1, 2008, pp. 1-10.

${ }^{43}$ Haller, as at note 30, p. 4.

${ }^{44}$ Preserved in letter of Goodhue to Lawrie, 2 December, 1923, incorporating copies of correspondence between Goodhue and Alexander for Lawrie's benefit. Nebraska State Capitol Building Correspondence. Box 35, Lee Lawrie Papers, Manuscript Division, Library of Congress, Washington, D.C.

${ }^{45}$ Letter, Bertram Grosvenor Goodhue to William E. Hardy. July 6, 1921. NCC. Cited in McCready, as at note 4, pp. 360, 367-368. See also Zabel, as at note 7, p. 297.

${ }^{46}$ Granted, Lawrie's addition of landscape elements (stylised stalks of corn behind the animals), the pairing of a mother with her resting calf, and the lowered heads of the bison localise, naturalise, and domesticate the image in a way that makes these images their own distinct beast, so to speak. However, it might be noted that even these elements might draw some inspiration from images Lawrie may have encountered while researching Assyrian palace art. Small-scale ivory furniture inlays had been found at the site of Nimrud from the earliest excavations, in which a popular theme was a mother cow with a nursing calf, very naturalistically portrayed. Stylised flowering plants also feature in proximity to human and animal figures in many ivory scenes. The ivories with these characteristic motifs were produced in the Levant and sent to Assyria as tribute; by the 1920s scholars had long recognised the presence of different regional styles in 'Assyrian' ivories, but then as today these ivories are still usually grouped with Assyrian styles in scholarly and popular books. The correspondence between the mother and calf motifs of these ivories and Lawrie's mother bison and calf are not close enough to make me certain that these ancient ivories were also in Lawrie's mind, but it does not seem entirely impossible that Lawrie would have encountered these images and been impressed by the theme. See G. Herrmann, S. Laidlaw, and H. Coffey, Ivories from the North West Palace (1845-1992), London, British Institute for the Study of Iraq, 2009, at pp. 53-54, 157159.

${ }^{47}$ H. B. Alexander, 'Nebraska State Capitol: Synopsis of Decorations and Inscriptions', TS, n.d, (submitted to the Capitol Commission in 1926), State Building Division, Nebraska State Capitol, 4. Cited in T. J. Garvey, 'Strength and Stability on the Middle Border: Lee Lawrie's Sculpture for the Nebraska State Capitol', Nebraska History, vol. 65, 1984, pp. 156-178 at p. 163.

${ }^{48}$ Alexander writes to Goodhue: 'In our first conversation you suggested permitting the inscription to sun [sic] over the shoulder or body of the buffalo, in Assyrian style'; Goodhue suggested that he wanted to keep this idea in revised, unwinged versions of the sculpture. Preserved in letter of Goodhue to Lawrie, 2 December, 1923, incorporating copies of correspondence between Goodhue and Alexander. Nebraska State Capitol Building Correspondence. Box 35, Lee Lawrie Papers, Manuscript Division, Library of Congress, Washington, D.C.

${ }^{49}$ In his article for the Nebraska State Journal, Alexander speaks of the 'vanished life of the Indian'; as at note 21.

${ }^{50}$ Haller as at note 30, p. 4.

${ }^{51}$ See for instance, his sculptures for the interior of the University of Chicago Chapel and even more so his Ten Commandments-holding 'Angel of the Old Dispensation' for the Church of the Heavenly Rest in New York City, both with Goodhue. Agard, as at note 10, p. 206, and discussion of its role in softening the building's contours on p. 210; Dickerson, as at note 16, p. 681.

${ }^{52}$ Assyrianising American eagles are also a feature of Lawrie's Soldiers and Sailors Memorial Bridge at Harrisburg, Pennsylvania, and above his entrance for the Louisiana State Capitol, discussed further belowalthough the influence in these cases is less certain.

${ }^{53}$ Alexander, letter to Meière, July 8, 1932. Hartley Burr Alexander Papers; cited at 'Nebraska State Capitol : House of Representatives (West Legislative Chamber) Entrance Door - International Hildreth Meière Association Inc'. n.d. Accessed June 18, 2018. https://www.hildrethmeiere.org/commissions/nebraska-state-capitol-house-ofrepresentatives-entrance-doors.

${ }^{54}$ Ibid.

${ }^{55}$ J. H. Breasted, Ancient Times: A History of the Early World, Boston, Ginn and Company, 1916, 149-150. The most comprehensive recent study on the Sacred Tree, with careful attention to the history of interpretation, is M. Giovino, The Assyrian Sacred Tree: A History of Interpretations, Göttingen, Vandenhoeck \& Ruprecht, 2007. 
${ }^{56}$ Breasted describes the Assyrian winged disk of Assur as derived from the Egyptian solar disk, clearly the interpretation Alexander and Meière worked from. Ibid, 149.

${ }^{57}$ This is how the door is explained on the official website of the Capitol: 'The leather doors of the West Chamber show the agricultural foundation of Western Civilization in the ancient middle eastern region. With the Assyrian man and woman planting a tree of life under an Egyptian sun'. 'Nebraska State Capitol'. n.d. Accessed June 18, 2018. http://capitol.nebraska.gov/building/rooms/west-chamber/.

${ }^{58}$ Layard, 1849, as at note 29, pl. 2; see also Cohen and Kangas, as at note 29.

${ }^{59}$ It had been taken from a temple in Sippar, a city in what is now central Iraq, to Susa as booty when the Elamite king Shutruk-Nahhunte sacked Babylon in 1155 BCE.

${ }^{60}$ Breasted, as at note 55, p. 128.

On the use of this volume by the Capitol team, see Haller, as at note 30, p. 4, especially n. 3 .

${ }^{61}$ Breasted, as at note 55, pp. 130-131. In the various revisions of our understanding of this text and other ancient Near East 'law codes' over the course of the twentieth century, scholarly consensus now holds that such texts were not used in any real sense as codes of government. They should be understood as literary royal inscriptions, and the tradition of copying and transmission as part of the Babylonian scribal curriculum. For a succinct overview of some of these issues see M. T. Roth, 'Mesopotamian Legal Traditions and the Laws of Hammurabi', Chicago-Kent Law Review, vol. 71, 1995, pp. 13-39.

${ }^{62}$ For scholarly reactions to the Stele of Hammurabi in the United States shortly after its discovery, see G. S. Duncan, 'The Code of Moses and the Code of Hammurabi', The Biblical World, vol. 23, no. 3, 1904, pp. 188-193; I. M. Price, 'The Stele of Hammurabi', The Biblical World, vol. 24, no. 6, 1904, pp. 468-472; G. E. Vincent, 'The Laws of Hammurabi', American Journal of Sociology, vol. 9, no. 6, 1904, pp. 737-754.

${ }^{63}$ Arp points out certain mistakes in the cuneiform inscription, some of them caused by joins in the stonework which have interrupted signs. D. Arp, “An Eye for an Eye": Examining a Cuneiform Inscription on the Nebraska State Capitol', Sculpture Journal, vol. 22, no. 1, Jan. 2013, pp. 139-142.

${ }^{64}$ M. T. Roth, Law Collections from Mesopotamia and Asia Minor. 2nd ed., Atlanta, Scholars Press, 1997, p. 121.

${ }^{65}$ Quoted in the American Standard Version, published in 1901 and a truly 'standard' translation in seminaries and in American life since, the antecedent of today's New Revised Standard Version; used here because it would have been perhaps the most likely familiar, modern translation in circulation in the 1920s. See also Exodus 21:2225, Deuteronomy 19:21.

${ }^{66}$ These claims for the moral superiority of the Israelites over earlier Babylonians had to ignore that these same Biblical codes still differentiated between slaves and free and Israelites and strangers, as Hammurabi's did between social classes, and that there are other reasons, beyond the moral, why different societies might understand social status or family relationships differently.

67 'Hammurapi' is in fact a more accurate rendering of the Akkadian. I use 'Hammurabi' because it is more recognisable to non-specialists, and because it is used on the Nebraska State Capitol itself.

${ }^{68}$ Breasted, as at note 55, pp. 131-132.

${ }^{69}$ One group of figures around the North Portal main entrance to the Capitol show 'Constant Guardians of the Law': a personified female Wisdom, male Justice, male Power, and female Mercy. Alexander explained that style and imagery render Wisdom as Oriental, Justice as Greek, Power as Roman, and Mercy as Christian-indicated both by Lawrie's style and by the symbolism of a lamb that she carries. See Haller, as at note 30, p. 13, n. 19.

${ }^{70}$ It also shows the care put into the building at every level: the inscription would have been incomprehensible to its creators and any visitors (barring the few Assyriologists scattered around the country at a few academic institutions), but Alexander and Lawrie still clearly carried out extensive research to choose an inscription with meaning.

${ }^{71}$ V. Kubly, The Louisiana Capitol: Its Art And Architecture, Gretna, Pelican Publishing, 1995, pp. 15-24; J. W. Sheire, 'Louisiana State Capitol'. National Register of Historic Places Inventory—Nomination Form. National Park Service, n.d.

${ }^{72}$ J. W. Sheire, 'Louisiana State Capitol'. National Register of Historic Places Inventory-Nomination Form. National Park Service, n.d.

${ }^{73}$ H.-R. Hitchcock and W. Seale, Temples of Democracy: The State Capitols of the U.S.A, 1st edition, New York, Harcourt Brace Jovanovich, 1976, pp. 282-283. This assessment is quoted in the National Register of Historical Places Inventory Nomination Form for the Louisiana State Capitol, which primarily assigns historical merit to the building for its interesting associations with Long's colourful career.

${ }^{74} \mathrm{Kubly}$, as at note 71 , p. 83. 
${ }^{75}$ This Hammurabi is less integrated into the architectural form of the building, portrayed in shallow relief, holding a tablet rather than tapering into inscription and stone work. In this respect it is a more conventional frieze image and not architectural sculpture in the sense that Lawrie himself understood his sculptures for Nebraska, as truly a part of the building in every sense.

${ }^{76}$ Dickerson, as at note 16, pp. 681-683.

${ }^{77}$ Meière also provided ceramic work for the Chapel. See E. J. Goodspeed, The University of Chicago Chapel: A Guide, Chicago, University of Chicago Press, 1928.

${ }^{78}$ On this work, the imagery of the Tympanum, and its ideological background see M. T. Larsen, 'Orientalism and Near Eastern Archaeology', in D. Miller et al. (ed.), Domination and Resistance, London, Routledge, 1989, pp. 229-239 at pp. 229-231; G. Emberling, 'Views of a Museum: The Extraordinary Collection of the Oriental Institute, University of Chicago', The Canadian Society for Mesopotamian Studies Journal, vol. 4, 2009, pp. 29-35 at pp. 3435.

${ }^{79}$ J. H. Breasted, The Oriental Institute, Chicago, University of Chicago Press, 1933, p. 103.

${ }^{80}$ In works of Ellerhusen and Lawrie, the bison emerges as an animal that can be flexibly deployed either to represent Western civilisation (now reposing in America) and 'us', or Native American civilisation and an exotic, semi-mythical 'other', as in the Nebraska State Capitol's Assyrianising examples. Its inclusion here makes clear that the Oriental Institute defines the culmination and stewardship of the West as now vested in America, not in the European nations represented in some of its figures-not surprising for an American, midwestern educational institute.

${ }^{81}$ As at note 79 , p. 108.

${ }^{82}$ Lawrie also featured an image of the Nebraska Capitol in his design for Goodhue's tomb, as the centre of an imagined architectural heaven crowned with Goodhue's finest work; Schwartzman and Gee, as at note 6, pp. 122123.

${ }^{83}$ Letter of Lawrie to Goodhue, October 13, 1923. Nebraska State Capitol Building Correspondence. Box 35, Lee Lawrie Papers, Manuscript Division, Library of Congress, Washington, D.C.

${ }^{84}$ Letter of Lawrie to Caroline Ransom Williams, June 13, 1924. Nebraska State Capitol Building Correspondence. Box 35, Lee Lawrie Papers, Manuscript Division, Library of Congress, Washington, D.C.

Ransom Williams was another Egyptologist, a former doctoral student, friend, and colleague of Breasted. She was told by Breasted about Lawrie's work and was interested in including his modern interpretations of Egyptian imagery in her lectures. In return she extensively advised him on good ancient models for his Akhnaton sculpture and sent him photographs of Akhnaton and Nefertiti sculptures in the Ägyptisches Museum in Berlin.

${ }^{85}$ Bertram Grosvenor Goodhue to Hartley Burr Alexander, 11 August 1923; Scripps, Nebraska State Capitol; quoted in Haller, as at note 30, p. 19, n. 3.

${ }^{86}$ A cuneiform inscription also appears on the Lawrie-designed sculpture above the Sterling Memorial Library entrance at Yale, another late, Goodhue-initiated project (completed by Yale's presiding architect, James Gamble Rogers). In this case, the cuneiform passage comes from an Ashurbanipal inscription (r. 668-627) and was selected by Raymond P. Dougherty, curator of the Yale Babylonian Collection from 1926 to 1933. Yale University Library, as at note 40, p. 82 .

${ }^{87}$ It is significant that in this period ideas about architectural decoration tried out in state capitols were later taken up in the national capitol, another indication of influence flowing from Nebraska to bigger and more established locations and not vice versa.

${ }^{88}$ Adolph A. Weinman papers, 1890-1959, Reel 5890, Frame 946: 39 of 96. Notes, undated. Archives of American Art, Smithsonian Institution Washington, D.C.

89 'About Relief Portrait Plaques of Lawgivers'. n.d. Architect of the Capitol | United States Capitol. Accessed June 20, 2018. https://www.aoc.gov/art/relief-portrait-plaques-lawgivers/about-relief-portrait-plaques-lawgivers.

${ }^{90}$ The idea for the sequence was apparently not Lawrie's. Lawrie was asked to serve as consultant by the architect Francis P. Sullivan and worked under him and David Lynn, then Architect of the Capitol. U.S. Capitol Building Correspondence, Box 42, Lee Lawrie Papers, Manuscript Division, Library of Congress, Washington D.C.

${ }^{91}$ Lawrie to Thomas Hudson Jones, July 7, 1950. U.S. Capitol Building Correspondence, Box 43, Lee Lawrie Papers, Manuscript Division, Library of Congress, Washington D.C. 